\title{
OBITUARIES
}

\section{Mr. I. H. Burkill}

Mr. Isaac Henry Burkill, distinguished for his work on the useful plants of the tropics, died on March 8, after a short illness, in his ninety-fifth year. He was born near Leeds and educated at Repton School and the University of Cambridge. On graduating in 1891 he was awarded a scholarship by his College (Gonville and Caius) and appointed assistant curator of the University Herbarium, remaining at Cambridge until the end of 1896, during which period he and $J$. C. Willis collaborated in extensive field work.

Their earliest investigations concerned the epiphytic vegetation of pollard willows by the River Cam; their main work was in Glen Clova, where they carried out an elaborate investigation of pollination, recording more than 17,000 insect visits to flowers. Burkill's herbarium work introduced him to the floras of France and Switzerland, and then a collection of specimens from the Pacific, which resources at Cambridge did not enable him to name, led him to visit Kew, where his interest in tropical plants began. He was appointed to the Herbarium staff at the Royal Botanic Garden, Kew, from 1897, and two years later transferred to the Director's office, where he was introduced to the many aspects of tropical economic botany with which Kew was concerned.

Burkill left Kew at the end of 1900 on appointment as assistant to Dr. G. Watt, reporter on economic products to the Government of India. Watt had written his Dictionary of the Economic Products of India, and had been requested to write a shorter version, on Commercial Products; he had also in hand the arrangement of a new wing of the Indian Museum devoted in part to economic products. Burkill took over the Museum work, and also travelled extensively, visiting markets where local produce was on sale and making reports for use in the new Dictionary, and during these travels he pursued his own work on floral biology. At Caleutta he met Dr. D. Prain, superintendent of the Botanic Garden (later director at Kew), and became interested in the economie plants which were in cultivation there at Watt's request; these included a large number of yams. Thus began the collaboration of Prain and Burkill in an investigation of the wild and cultivated species of Dioscorea in Asia, which resulted in a large monograph much later $(1936,1938)$.

After the publication of Watt's second Dictionary, Burkill's status was changed, and he felt unsettled, not seeing a prospect of doing the work he wished to do. However, he did have a major opportunity for botanical exploration when he accompanied the Abor Expedition (November 1911-March 1912) to the outer range of the Himalayas near the junetion of the Dihang River with the Brahmaputra. On his return from the expedition he was offered the post of director of Gardens, Straits Settlements, in succession to H. N. Ridley.

At Singapore he found much reorganization necessary, and little skilled assistance. Ridley had left nine months previously: his methods had always been haphazard; he never understood Burkill's mothodical and scholarly nature. The First World War brought continuous staffing difficulties, and an assistant director with botanical qualifications, appointed in 1914, did not arrive until 1919. Burkill had duties in Penang and Malacea, which necessitated travel, and this he used to collect specimens and enlarge his knowledge of native plants. He collated the records of plants introduced to the economic garden (where the Hevea trees, source of most of Malaya's rubber plantations, had been planted) and made new intro. ductions, including local yams. He made contact with
F. W. Foxworthy, forest research officer at Kuala Lumpur, with whom he collaborated in investigations of forest trees. The Governor of the Straits Settlements (Sir Laurence Guillemard), hearing of Burkill's growing files on useful plants, proposed that he should write a Dictionary of the Economic Products of Malaya after his retirement. With this in view, Burkill spent much time in travel during his last three years in Malaya, collecting specimens in local markets, with notes on local names and uses; he also made a special effort to collect data on plants believed to be of medicinal value. His most important publication during these years was a survey of some 1,500 oriental vernacular names of yams, with comments on the origins of the cultivated species and on the wanderings of man.

After his retirement in 1925 he settled at Leatherhead, and went regularly to Kew, where he elaborated his card index of references. In three years he accumulated 36,000 of these, and only then began writing. The Dictionary was published, in two volumes, in 1935. It is the most important single work of the present century on useful tropical plants. It is particularly noteworthy for the scholarly fullness and accuracy of the information on the origins and the history of human exploitation of the various species; and it contains the largest and most critical collection of Malay plant names ever recorded. It also contains contributions on animal produce, fish and minerals, but these occupy only a small fraction of the whole.

After completing this great task, Burkill returned to the family Dioscoreacere. He cultivated Tamus in his garden and investigated its morphology and anatomy in comparison with Dioscoreas in cultivation at Kew. His help was asked for by Belgian and French botanists concerned with Dioscorea species in Africa, and his investigations of these led to new ideas about the evolution and spread of the family, to which his last paper (1960) was devoted.

Burkill accepted appointment as botanical secretary of the Linnean Society in 1937, and continued through the difficult years to 1944. In 1951 he delivered the Hooker Lecture to the Society on "Habits of Man and the Origins of the Cultivated Plants of the Old World". The Society awarded him the Linnean Gold Medal in 1952.

His last work was entitled Chapters on the History of Botany in India, published by the Bombay Natural History Sooiety during 1953-63, to be issued shortly in book form by the Botanical Survey of India. He went to great trouble to collect and verify biographical data of the many persons concerned, and his last visit to Kew was in connexion with this work. His failing eyesight in his last years wes a trial to him, though his mind remained alert and active; his wife helped most faithfully by writing much of the last chapter at his dictation.

\section{R. E. Holtum}

\section{Prof. L. H. May}

THE sudden death on April 3 of Prof. Lancelot Harris May, professor of plant physiology, Waite Agricultural Research Institute of the University of Adelaide, means that botanical science has suffered a great loss. After serving in the Royal Australian Air Force, Prof. May graduated from the University of Adelaide in 1949 with first-class honours in botany. He held a Services Canteens Trust Fund overseas scholarship during the early fifties at the Imperial College of Science and Technology, London, where he worked on sugar metabolism in plants with Dr. H. K. Porter and the late Prof. F. G. Gregory. He was awarded a Ph.D. degree by the University of 